\title{
高所登山は「死と隣り合わせ」か：高所登山家のリスクの捉えと リスク対処方略を明らかにする
}

\author{
村越＼cjkstart真1） 中村美智太郎1）＼cjkstart河合 美保2)
}

Shin Murakoshi ${ }^{1}$, Michitaro Nakamura ${ }^{1}$ and Miho Kawai2: Do high altitude mountaineers have a death wish?: Investigation of risk perception and risk management. Japan J. Phys. Educ. Hlth. Sport Sci. 59: 653-671, December, 2014

\begin{abstract}
Perception and management of risk by high altitude mountain climbers were investigated by qualitative analysis. Reports of high altitude mountain climbing collected from 3 books and 15 articles from mountaineering magazines were analyzed by the KJ method and transcripts derived from semistructured interview of 6 distinguished Japanese expert mountain climbers were analyzed by M-GTA. The results indicated the following trends: 1 ) The desire for more fascinating high altitude mountain climbing routes inevitably leads climbers to face difficult and uncertain situations. 2) Such climbers are highly aware of the uncertainty derived from the high altitude environment and the exertion of climbing. 3) Because they are aware of this uncertainty, their decisions always waver between challenge and safety, and they always attempt to reduce the degree of risk. 4) Such efforts consist of two phases: risk reduction prior to the climb, and on-site avoidance of risk, each being characterized by mental simulation, avoidance of uncontrollable situations, and endeavours to salvage a positive result. 5) After the climb, ambivalent cognition between reflection on their optimism and achievement also emerges. Among all, mental simulation primed by on-site signs of risk, and risk evaluation from the viewpoint of controllability were regarded as keys to staying alive in high risk situations during high altitude mountaineering. Through this risk perception and management process, high altitude climbers possess a contradictory sense of "controllable risk" that enables them to engage in high risk activity. Overall, the characteristics of risk perception and management were similar among the materials obtained from books/magazine articles and interview transcripts. The characteristics of climbers' perception and risk management were rationalized by the characteristics of the natural environment in which they were climbing, and also from the viewpoint of the situated action. The possible application of these findings to risk management in outdoor sports was also discussed.
\end{abstract}

Key words : M-GTA, controllability, on-site signs, awareness of uncertainty, effort of risk reduction キーワード : M-GTA, 制御性, オンサイトの兆候, 不確実性の自覚, リスク軽減努力

\section{I 緒 言}

\section{1. 登山とリスク}

登山は幅広い年代に愛好されるアウトドアス ポーツだが，管理されていない自然の中で行われ るため，多様なリスク注1)を秘めている。日本で
の登山による遭難人数は年間 1700 人を超え, 死 者・行方不明者は登山以外の目的も含めると 284 人にのぼる（警察庁生活安全局地域課，2013）. とりわけ高所登山注 2)には, 厳しい気象条件や自 然環境による多くのリスクがある。熟練した登山 家ですら, 凍傷による指の切断, 転滑落による大 けがに遭遇することも希ではない。加えて，ひと
1）静岡大学教育学部

干422-8017 静岡市駿河区大谷836

2) 静岡大学大学院教育学研究科

干422-8017 静岡市駿河区大谷836

連絡先 村越 真
1. Faculty of Education, Shizuoka University 836 Oya, Suruga-ku, Shizuoka 422-8017

2. Graduate school of Education, Shizuoka University 836 Oya, Suruga-ku, Shizuoka 422-8017

Correspondingauthorehsmura@ipc.shizuoka.ac.jp 
たび事故が起これば救助活動が迅速に行われにく いというリスクを高める要因もある。 $8000 \mathrm{~m}$ 級 全14座登頂を日本人として初めて成功させた竹 内洋岳が，10座目になるダウラギリで雪崩に巻 き込まれた時のことを次のように語っている。

「誰も助けに来ないことはわかっていましたか ら,これはもう, 助からないって, 冷静に判断で

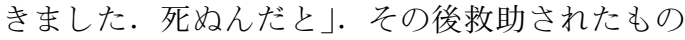
の，C2 で居合わせた医者に「残念だが明日まで 持たない．今のうちに家族にメッセージを残せ」 と宣言された（塩野，2011）。紹介したのは 1 つ の事例にすぎない。しかし，優秀な高所登山家の 中でも, 登山中に命を落とす者は少なくない。こ うした事実から，高所登山は「死と隣り合わせ」 の行為であり, 高所登山家は「命知らず」とすら 感じられる.

このようなリスクの高いスポーツ活動者の性 格や行動特性を捉えようとする研究によれば, アウトドア活動などの非日常的な覚醒・リスク や，制御できないことへの選好に関する下位尺度 等によって構成される刺激欲求（Zuckerman and Kuhlman, 2000) には，低いリスクのスポーツ 活動者との間に差が見られ，なかでも下位尺度で ある TAS（スキルと冒険）には差が見られる一 方で，日常的なリスク志向を説明する衝動性 (Eysenck and Eysenck, 1977）には差がなかった (Jack and Ronan, 1998). 同様の結果は Goma-iFreixanet（2004）のレビューによっても確認さ れた。登山家は新奇な刺激とそこから生久出され る覚醒や体験を追求する傾向が強いが，それは日 常でのリスク志向のように衝動性によるものでは ないと考えられる。

その一方で，登山者の中でとりわけリスクの 高いと考えられる高所登山とそれ以外の登山者 を比較した研究では, 刺激欲求と衝動性のいずれ においても差がないという結果も得られている (Goma-i-Freixanet, 1991)。 また刺激欲求は挑 戦するルートの難度により定義されたリスク志 向を十分説明していなかった（Llewellyn and Sanchez, 2008).さらに, アラスカのマッキン リーを目指した登山者 360 名に対するフィールド
での質問紙調査でも，高揚感や達成感が重要な要 素であり，リスク志向は登山の動機付けとして重 要な役割を占めていなかった（Ewert，1994）。 以上のような結果から，新奇な刺激による覚醒は 登山の魅力を構成しているものの，高所登山者は 必ずしもリスクそのものを求めている訳ではない と考えられる.これは刺激欲求が，概念的には新 奇な刺激による生理的覚醒を求める性格特性であ り，必ずしもリスクを犯すこと自体を求める特性 ではない (Zuckerman, 2007) ためかもしれない.

不確実性の高い環境での新奇な刺激の追求は, 予測できない結果をもたらすことがある，身体を 使うスポーツでは，これはけがの危険性にもつな がる。しかし，不確実性に対応するスキルを発揮 できれば，それは必ずしも失敗による損害の可能 性を意味しない，実際，登山家を含む高いリスク に従事する者のリスク志向に関する質問紙研究で は，リスクに関わる 2 つ下位尺度が見いださ れた。その一方はリスクを積極的かつ計画的に追 求する性向だが，もう一方は事前に注意深くリス クに対応する性向であった．前者は事故率や事故 寸前の状況であるヒヤリハットと正の相関を持つ が，後者には負の相関が見られた（Woodman et al., 2013). また高い自己効力感を報告するロッ ククライマーは, より難度の高いタイプの活動を 行っていた (Llewellyn et al., 2008; Llewellyn and Sanchez, 2008)。他者から見ればリスクの高 い活動も，高所登山家自身にとっては，必ずしも そうではないのかもしれない。

楽観主義バイアス（Weinstein，1980）あるい は制御の幻想（Langer，1975）といった認知的 バイアスにも同様のことが言える. 認知的バイア スがあると，実際よりも知覚されたリスクは低く なる、それによって他者が高リスクだと考えるこ とにも従事できる．しかし，危険の異なるロック クライミングに関する研究によれば, 楽観主義は 活動リスクに対する自己評価や他者との相対的な リスク評価には影響していないことや，危険度の 高い登り方では, 認知された能力や楽観主義は過 去のけがの経験によって低下していた（Martha et al., 2009). 同様の知見は, Jakas and Shaw 
（1996）にも見られた。すなわち，活動者はリス クの認知を自己の力量に合わせて調整していると 考えられる. 認知的バイアスとは，リスクに対す る見方が集団全体として偏っていることを説明す る概念である. 認知的バイアスと見えるものも， 特定の個人から見れば，彼（または彼女）のスキ ルに見合った適切なリスク認知であり，優れたス キルの結果としてリスク認知が低くなり，それに よって, より高いリスクのある行動に従事するこ とがでてきているのかもしれない，リスクに対す る見方がバイアスを受けたものかどうかは，彼ら のスキルや過去の経験を踏まえる必要がある.

以上のことより，Heimer（1988）が指摘する ように，スキルが大きな役割を果たすリスクのあ る活動ではリスク認知に関する多くの研究の題材 となった経済活動やギャンブル・薬物に関する行 動とはリスク認知が異なっているのかもしれな い. 実際, 概観した先行研究からは, 高所登山家 が高いリスクに挑む背後には, 過去の経験, リス クに対する性向が影響していることが示唆され る. 一方で, 彼らが経験やその性向の結果, リス クをどう捉え，具体的にどう対処しているのか， あるいはリスクの捉え方が対処にどう影響してい るのだろうか。こうした，リスク対処の動態を明 らかにすることは, 高所登山家の特徵を把握する 上で欠かせないと考えられるだけでなく，リスク の多い環境に打ける行動への示唆を得ることがで きると考えられるが，群の性向を平均值的に捉え る質問紙研究では十分に明らかになっていない.

高い能動的リスクのあるアウトドアスポーツの 活動者がリスクを主観的にどう捉えているかに関 する，実践場面を対象とした質的研究がある。世 界トップクラスのアドベンチャーレース選手を対 象にした半構造化面接に基づく研究（Schneider et al., 2007) では,「リスクへの社会化」,「リス クの場」,「リスクの媒介」,「リスクとのコーピン グ」，「刺激」がカテゴリーとして見い出された. 対象者は，レースには多様なリスクがあることに 気づき，それに対してポジティブ/ネガティブ両 面の感情が喚起される。またリスク行動を促進/ 抑制する多様な媒介要因やリスクに心理的に対処
していることを明らかにしている，その一方で， 得られたカテゴリー間の関連や，高いリスクに実 際にどのように対処しているのかについては触れ ていない.

\section{2. 研究上の課題と本研究の目的, および研究 の概略}

先行研究は, 高所登山家が登山のリスクをどう 捉えているかについての推測の手がかりを与えて くれる。しかし，彼らがリスクに対してどのよう に対処することで致死的な結末を回避している か，リスクへの対処方法はリスクの捉え方とどの ような関係にあるのか，といったリスクの把握か ら対応に至る動態とそれに影響する認知・行動的 要因を, 十分に明らかにはしていない。認知心理 学における人間の知的行動の研究は, 物理学やパ ズルのような定型的な問題解決を対象としたもの から，より自然な文脈に適応した問題解決行動の メカニズムをとらえようとする意図によって，高 い対人的スキルが必要な職業領域における実践知 の研究（例えば，金井・楠見，2012; Sternberg et al., 2000)，あるいは消防士のように高リスク の職業における自然主義的意思決定の研究 (Klein, 1998) へと深まってきた. 前者では実践 の中で獲得された課題解決に資する言語化しにく い知識が, 複雑な社会環境の中での課題解決にど のように貢献しているかが検討され，後者では, ゴールが十分に定義されていない複雑で不確実な 領域での問題解決における高いパフォーマンスを 対象としている（Ross et al., 2006)。これらの研 究領域の対象と同様に, 高所登山も自然の中とい う複雑かつ多様なリスクの中で行われる. 多くの 場合新規ルートの登攀が目指されるが，同時に生 還することは第一義的な価值を持つ，そのため， 新奇な状況に抢けるリスクを適切に評価し, 未経 験の方法によって状況に応じてリスクに対応し， 場合によっては登山を中断する必要もある。これ らの問題解決に当たっては, 実践の中で身につけ た知識が効果的に働いていると考えられる. 従っ て, 彼らのリスク対応を明らかにすることは, 実 践知や自然主義的意思決定の研究にも資すると考 
えられる。

そこで本研究では，高所登山家が登山に打ける 高いリスクをどう捉えているか，高いリスクへど う対処しているか，リスクの捉えと対処にはどの ような関係があるのかを明らかにすることを目的 とした. 先行研究の概観から示されたように, 個 人の経験や性向に依存する彼らのリスクの捉えや その動態は質問紙研究では把握することが難し い.このため, 本研究では質的研究法である MGTA（木下，2003）を本調査に用いるとともに， KJ 法（川喜多，1967）による予備調査を行い， 得られた概念の再現性を確認することで, 結果の 信頼性を高めることとした，予備調査では，登山 雑誌に掲載された手記や高所登山家を対象とする インタビュー記録を対象とした。これらは本研究 のテーマに合致した目的で得られたものではない が，多くの優れた高所登山家のリスクに対する考 え方を得られる。これらの資料は，必ずしもリス クやそれに対する対処を記述することを目的とし ていないので，KJ 法によって，彼らのリスクの 捉え方と対処法を整理するとともに，仮説構築と してその関係を検討した。本調査では，日本を代 表する 6 名の高所登山家を対象としてインタビ ューを行い，第 1 に，高所登山において個人的 な経験がリスクの捉えをどう規定し，また経験と リスクの捉えがリスク対処にどう影響しているか といったリスク対処の動的な側面を明らかにする ことを目的とした。ささらに，得られた知見をアウ トドアスポーツのリスク対処の改善に活用すると

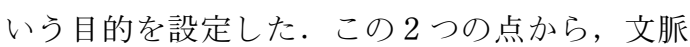
を重視して，意味に深い解釈を可能にすること， 相互作用に基づく動態を把握するのに適し，かつ 得られた知見を実践に活用するのに適した MGTA（木下，2007）による分析がふさわしいと 考えた.

時には死と隣り合わせの高所登山や競技性の高 いアウトドアスポーツは, 受容するリスクという 点で一般的なアウトドアスポーツとは全く異なる ように感じられる。しかし，彼らも「最も大事な ことは生きているということ,レースは二の次」 （Schneider et al., 2007）と捉えている.この言葉
からは，高いリスクのアウトドアスポーツを行う アスリートも，無条件にリスクを受容している訳 ではなく，自分自身で設定した限界レベルを超え ないようにリスク対処していると考えられる。 も しそうであるなら, 本研究の知見は, 漸増傾向に ある一般の登山の遭難防止や自然体験活動におい て，活動者がどのようにリスクを捉え，対処すべ きかについての一定の指針を与えることも期待さ れる。

\section{II 矛備調查}

\section{1. 方法}

日本の代表的な登山雑誌である「山と渓谷」 「岳人」に 2006 年から 2010 年の 5 年間に掲載され た記事より，高所登山に関する概ね 2 ページ以 上の記事のうちリスクに関連した記述があるもの 17編，121ページ分を選んだ。標準的な $\mathrm{KJ}$ 法の 手順（川喜多，1967）により，テキストから163 枚の紙片を作成し，2段階でグループ編成し，見 出しを付けるとともに図解を行った。ただし，ラ ベルは文脈を重視するため，比較的長い部分を切 り出して作成した。この作業は第 1 著者によっ て実施された。

\section{2. 結果}

163枚の紙片から，34の小グループとそれを統 合する10の大グループが生成できた，表 1 に， グループ名と紙片が国内外の登山家のそれぞれか らいくつ産出されたかを示し, 図 1 に図解を示 した．また以下に図解を文章化したものを示す。 なお，【】は大グループ，［］は小グループの 見出しを示す.

【不確定要素が冒険の要件】は, 高所登山の危 険は完全には制御できない不確定要素を含むが故 に，冒険としての価值があると捉えられることで あり，比較的多くの紙片から構成されていた，不 確実な環境の中で無事生還するための要件とし て, 事前の準備と登山時の確実な行為実行の 2 つがあった．前者が【精緻な計画と準備によるリ スクの制御】であり，[精緻な計画づくりと綿密 
表1 KJ 法により産出されたグループと大グループ

\begin{tabular}{|c|c|c|c|}
\hline 大グループ & グループ & 国外 & 国内 \\
\hline $\begin{array}{l}\text { 不確定要素が } \\
\text { 冒隃の要件 }\end{array}$ & - & 9 & 2 \\
\hline \multirow{3}{*}{$\begin{array}{l}\text { 精緻な計画と } \\
\text { 準備によるリ } \\
\text { スクの制御 }\end{array}$} & 精緻な計画づくりと綿密な準備 & 6 & 4 \\
\hline & 論理的ルートの発見 & 3 & 3 \\
\hline & リスクの意識的制御 & 11 & 2 \\
\hline \multirow{3}{*}{$\begin{array}{l}\text { リスクにより } \\
\text { 生まれる魅力 } \\
\text { と意欲 }\end{array}$} & 危険を制御する魅力 & 2 & 4 \\
\hline & $\begin{array}{l}\text { 魅力的ルートにより喚起さ } \\
\text { れる意欲 }\end{array}$ & 2 & 5 \\
\hline & 危機的状況における強気 & 2 & 0 \\
\hline \multirow{3}{*}{$\begin{array}{l}\text { 困難が生み出 } \\
\text { す否定的感情 }\end{array}$} & 事前に感じる強烈な恐怖 & 0 & 4 \\
\hline & 制御不可能性への不安 & 2 & 3 \\
\hline & 極限状況での精神的消耗 & 1 & 3 \\
\hline \multirow{2}{*}{$\begin{array}{l}\text { リスク場面へ } \\
\text { の覚悟 }\end{array}$} & 気持ちの準備が整う時 & 3 & 0 \\
\hline & 選択肢を失うことによる集中 & 0 & 2 \\
\hline \multirow{4}{*}{$\begin{array}{l}\text { 行動中のリス } \\
\text { ク把握之最 } \\
\text { 悪事態の想定 }\end{array}$} & 極限状況の自覚 & 1 & 8 \\
\hline & 確実なリスクの評価 & 4 & 4 \\
\hline & $\begin{array}{l}\text { 最悪の事態の客観的かつ詳 } \\
\text { 細な想定 }\end{array}$ & 1 & 5 \\
\hline & 現場でしかわからないこと & 1 & 2 \\
\hline \multirow{5}{*}{$\begin{array}{l}\text { 極限状況での } \\
\text { 意志決定と行 } \\
\text { 動の確実な実 } \\
\text { 行 }\end{array}$} & 極限状沉に対応した意志決定 & 6 & 8 \\
\hline & 遭難事例を教訓とした意志決定 & 0 & 1 \\
\hline & $\begin{array}{l}\text { 苦痛を伴う作業の細心・確 } \\
\text { 実な実行 }\end{array}$ & 1 & 4 \\
\hline & $\begin{array}{l}\text { 集中力による行動のコント } \\
\text { ロール }\end{array}$ & 0 & 2 \\
\hline & ぶつかり合う意見 & 0 & 2 \\
\hline \multirow{6}{*}{$\begin{array}{l}\text { 高所登山に必 } \\
\text { 要な的特性 }\end{array}$} & 臆病さの自覚 & 2 & 1 \\
\hline & $\begin{array}{l}\text { 能力を超えた現実に対する } \\
\text { 諦めのよさ }\end{array}$ & 5 & 8 \\
\hline & 困難を楽しむ力 & 0 & 2 \\
\hline & 正しい行動を選択できる直観 & 3 & 2 \\
\hline & 熟練による自動化 & 2 & 1 \\
\hline & 諦めずに全力を尽くす & 3 & 5 \\
\hline \multirow{5}{*}{ 行為への省察 } & 失敗の自覚 & 0 & 2 \\
\hline & 直感への疑問 & 1 & 0 \\
\hline & 困難な経験によって得た自信 & 1 & 0 \\
\hline & 野心 · 邪心による直感の鈍り & 0 & 2 \\
\hline & 死への真剣な考慮 & 0 & 2 \\
\hline \multirow{2}{*}{ 相矛盾する感 } & 無事終えた時の複雑な気持ち & 0 & 2 \\
\hline & 死に対する矛盾した考え & 0 & 1 \\
\hline
\end{tabular}

† :「国外」は国外登山家によるラベル産出数,「国内」 は国内登山家によるラベル産出数
な準備］[論理的ルートの発見］［リスクの意識的 制御]の 3 つのグループから構成され, 非常 に多くの紙片を含んでいた［リスクの意識的制 御]では, 冒険には不確実性が不可欠であるから こそ，危険をしっかりと捉え，制御することの重 要性が常に意識されていた.リスクを制御するた めに，[精緻な計画づくりと綿密な準備］が必要 となる，準備は, 過去の遠征隊の日記を詳細に調 ベること,クライミングに必要なムーブを絞って 頭の中でプログラミングすること, トレーニング することなど多岐にわたる，冒険的だがリスクの 制御された［論理的ルートの発見］も意識されて いた.

高所登山には【リスクにより生まれる魅力と意 欲】がある。能力の限界ぎりぎりのところでの [危険を制御する魅力] は， [魅力的なルートによ り喚起される意欲］につながり，[危機的状況に おける強気も，リスクを乗り越える意欲だと考 えられる. 極限状態での活動には, 【困難が生み 出す否定的感情】が生じた. 行為の前にはしばし ば [事前に感じる強烈な恐怖］[制御不可能性へ の不安］が感じられ，行為中にも [極限状況での 精神的消耗 $]$ が見られた. その一方で, 可能な限 りリスクが制御できたと実感でき，[気持ちの準 備が整う時], ネガティブからポジティブへ突然 の【リスク場面への覚悟】が生まれる。また登山 中には［選択肢を失うことによる集中］が得られ た.

綿密な準備をしても, 自然は常に変化し, 予測 外のことが起こる. 登山中のリスクへの対処は,

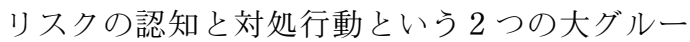
プから構成されていた. 認知面は【行動中のリス クの把握と最悪事態の想定】であり, 致死的な状 況にいるという [極限状況の自覚]，それに基づ く［確実なリスクの評価］と［最悪の事態の客観 的かつ詳細な想定］が行われていたが, 最悪事態 の想定には［現場でしかわからないこと］が活用 されていた．後者の対処行動は【極限状況での意 志決定と行動の確実な実行】であり, [極限状況 に対応した意志決定， [遭難事例を教訓とした意 志決定］が行われ，極限状況では［苦痛を伴う作 


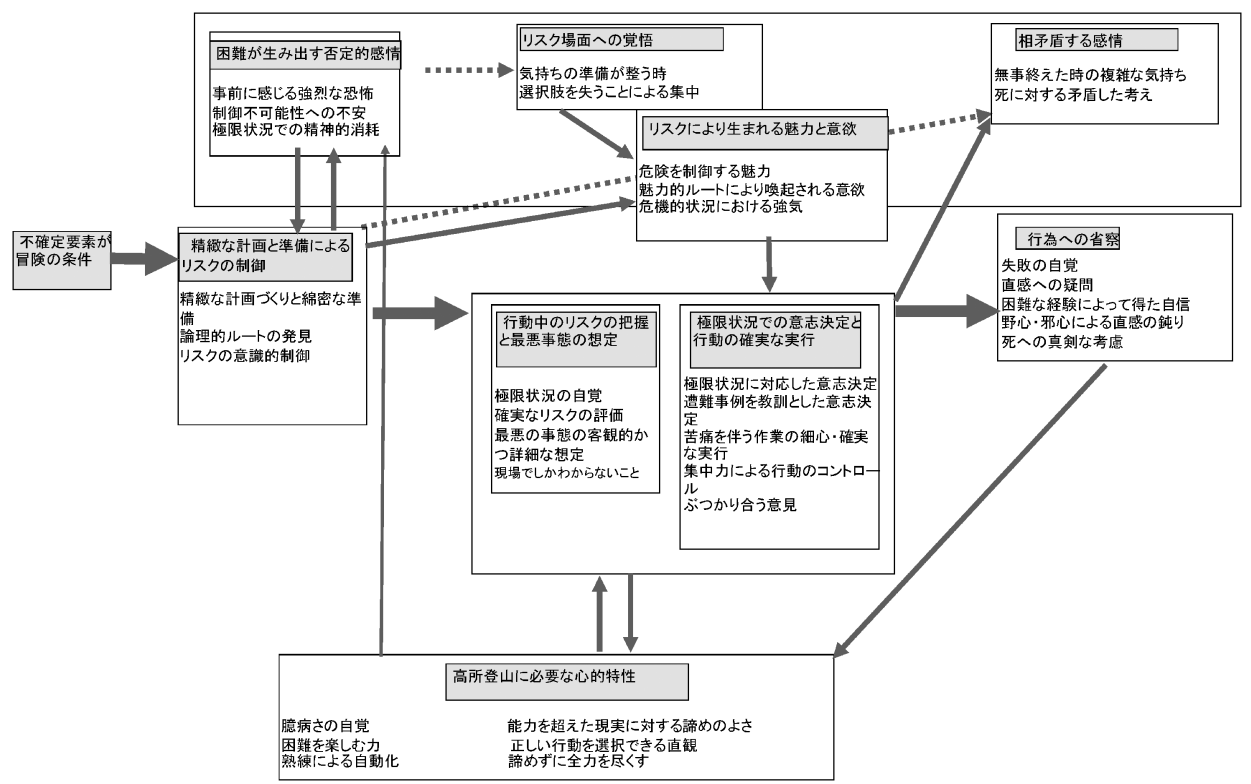

図 $1 \mathrm{KJ}$ 法によって得られた高所登山家のリスクの捉え，それにより喚起される感情およびリスクへの 対処方略

業の細心・確実な実行] [集中力による行動のコ ントロール］が必要であった．高いリスクと最悪 の事態の中にいるという自覚をもとに，困難な作 業を遂行するという意志決定とそれを確実に実行 するための集中力が生まれていると考えられる. また複数人による登山の場合には，[ぶつかり合 う意見]を調整する過程を通して，より確実な解 決策が生まれると実感されていた。

以上のような活動を可能にする【高所登山に必 要な心的特性】として，[正しい行動を選択でき る直観］[熟練による自動化］[諦めずに全力を尽 くす］［困難を楽しむ力］［臆病さの自覚］［能力 を超えた現実に対する諦めのよさが得られた。

危険の多い登山を終えると，登山家は【行為へ の省察】を行う。[困難な経験によって得た自信] の一方で，[失敗の自覚］も生まれる．正しいと 思っていた直感に対して, [直感への疑問], [野 心・邪心による直感の鈍り」があったというネガ ティブな省察が生まれた，そこから，[死への真

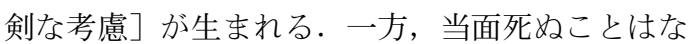
いが，生きることを奮い立たせてくれる何かを失 うという【相矛盾する感情】も生起した。

\section{III 面接調查に基づく M-GTA 分析}

予備研究の知見をもとに，日本を代表する高所 登山家を対象とした面接調査を実施し，その結果 をM-GTAによって分析することで，高所登山 家のリスクに対する捉え方やリスク対処の方略を 明らかにすることを目的とした。

\section{1. 方法}

1）協力者抢よびデータ収集

面接は，2011年 8 月から 2013 年 8 月にかけ て，第 1 著者により実施された。協力者 6 名は いずれも高所登山を実施する熟練した男性登山家 であった。うち 5 名は，国際的に著名な賞を受 けており，残り 1 名もそれに準じる実績があっ た、いずれも日本を代表する登山家と言える. 2011 年 8 月に 3 人の協力者に対して面接を行っ た後, 2 年間で 4 番目から 6 番目の協力者に対し て面接を行った～ 5,6 番目の協力者に対しては, それまでの面接結果やその分析を元に, 理論的サ ンプリングを意識した質問を含めた. 面接は, 各 協力者ごとに半構造化面接法によって行われた. 
面接の内容は, 主要な登山歴を聞いた後, 代表的 な登攀を取り上げ，準備や途中で行ったこと，そ こでのリスクの様子やそれに対してどう対処した か，あるいはどう考えたかを中心として，語られ る体験に対応しながら行われた．時間は 30 分か ら90分であった。面接を始める際, 研究の目 的，データの取り扱い，発表の匿名性とその限界 （発言内容は匿名によってのみ公表されるが，特 異な体験のため発言者が特定される可能性がある こと）を説明し，研究への協力の承諾を得た。ま た承諾により ICレコーダーによって録音した.

2) 分析手順

作成した逐語録を資料として，M-GTAの手 法（木下，2003，2007）による質的分析法を実施 した．分析焦点者は，「死のリスクを含む高所登 山を継続する高所登山家」であり，分析テーマは 「高所登山家が高いリスクをどう捉え，対処して いるか」とした。まず，最も豊かな内容を持った $\mathrm{A}$ の逐語録から分析テーマに関連する具体例を 取り出し，概念を生成した。その後，具体例をさ らに取り出すとともに，類似性や対極性を意識し て概念の生成を続け， 2,3 番目の協力者の分析へ と進みながら，概念の修正を行った。さらに，概 念間の時間的位置, 類似性, 対極性, 論理的な関 連性を踏をえて結果図を作成しながら，複数の概 念を包括するカテゴリーや，必要に応じてさらに 抽象度の高い上位のカテゴリーを生成した。

質的研究においては, 誰がデータに意味づけし ていくかを抜きにしての解釈作業は考えられない (木下, 2007). 特に, 本研究では, リスクをど う捉えるかという高所登山家の主観的意味づけの 仕方を研究対象としている。したがって，活動文 脈を踏まえた理解と解釈が必要だと考えられる. そこで，アウトドアスポーッにトップレベルで従 事した経験と公的研修機関での登山関係の講師の 経験を豊富に有し，アウトドアのリスクマネジメ ントの研究にも従事している第 1 著者が主とし て分析を行った。一方で，第 1 著者が生成する 概念の信頼性を担保するために，もっとも豊かな 内容を持つ協力者 $\mathrm{A}$ を対象として，第 2 , 第 3 著者も独立に概念を生成し，比較検討を行った。
さらに第 1 著者が中心になって生成した全ての 概念をもとに第 2 ，第 3 著者が独立して結果図の 作成を行い, 結果図の信頼性の確認を行った。こ れらの生成過程で, 協力者 1 名によって内容の 妥当性が評価された。第 2 著者は博士課程を修 了した倫理学の研究者, 第 3 著者は博士課程在 学中の心理学の研究者であった，その点から，本 研究が扱う主観的なリスクや対処行動を検討する 学識を有すると同時に, 質的研究についても一定 の知識とスキルを有していた。一方で，いずれも 本格的なアウトドアスポーツの経験はなく, 登山 についても一般的以上の知識は有していなかっ た。このような分析者によって生成された概念や ストーリーラインを第 1 著者のそれと比較する ことで, 得られた概念や動態が, 領域外の者にも 了解可能なものかどうかについても検討できると 考えられる。

\section{2. 結果}

逐語録約 137,000 文字から生成された概念は 33 ，バリエーションの数は表 2 に示した. 3 人の 著者が独立して生成した概念は概念名で違いが見 られたものの，運の自覚，リスクへのポジティ ブ/ネガティブな感情, 制御可能性という視点で のリスクの捉え, リスクへの積極的な対処, 対話 によるリスクへの対処，など登山におけるリスク への基本的な捉え方では共通点が見られた。一 方，リスクへの対処の具体的内容については，第 1 著者の生成した概念がもっとも包括的かつ詳細 であると同時に，プロセスに打ける概念の位置づ けが概念名に明示される傾向にあった．そこで第 1 著者の結果を基に概念をまとめた。一方で，第 1 著者の生成した概念を元に 3 者で独立して作成 した結果図では, 事前/登山中/事後という 3 つ の局面への分類, リスクの両義性による相反する 感情や認知が生まれる点, リスク対処の多局面性 など，中核的な特徵で 3 者に共通点が見られ た。そこで，第 1 著者の生成した結果図を中心 に，第 2 -第 3 著者と合議の上，最終的な結果図 を作成した。得られた結果図が図 2 である。［］ は概念名，【】はカテゴリー名であり，概念に 
表 2 M-GTAにより産出された概念, カテゴリー, バリエーションとその産出数

\begin{tabular}{|c|c|c|c|c|}
\hline カテゴリー名 & 概 念 名 & バリエーション & $\begin{array}{l}\text { バリエー } \\
\text { ション数 }\end{array}$ & $\begin{array}{l}\text { 産出 } \\
\text { 者数 }\end{array}$ \\
\hline \multicolumn{2}{|c|}{ 過酷な活動条件 } & - & - & - \\
\hline & 2 不確実性の自覚 & 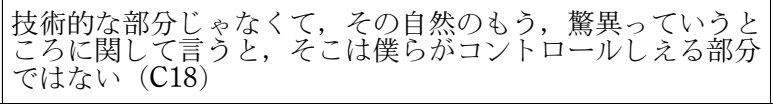 & 14 & 5 \\
\hline & \begin{tabular}{l|}
1 ミスが許されない \\
世界
\end{tabular} & $\begin{array}{l}\text { やっぱり，失敗は許されないし } 1 \text { 人が足引っ張っちゃうと全 } \\
\text { 員がバンザイになっちゃうし（D42） }\end{array}$ & 4 & 3 \\
\hline & 25困難の受容 & 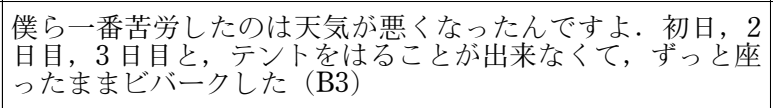 & 6 & 4 \\
\hline \multicolumn{2}{|c|}{ 18リスクの両義性の意識 } & $\begin{array}{l}\text { 危険と自分のモチベーションとのそのバランスを，今丁度見 } \\
\text { 極めるのに，丁度適した，なんていうのかな，経験をつんで } \\
\text { いる（A29） }\end{array}$ & 8 & 4 \\
\hline & \begin{tabular}{|l|}
5 不確実さに対する \\
不安
\end{tabular} & $\begin{array}{l}\text { それ (高山病) がどこで本格的に悪化するかっていうのはか } \\
\text { なり予測できないので. …とううう安ですね. (E8) }\end{array}$ & 10 & 6 \\
\hline & $\begin{array}{l}6 \text { 装備の安全側への } \\
\text { 志向 }\end{array}$ & $\begin{array}{l}\text { 天気は絶対に悪くなるものだというろうに思ってたので，と } \\
\text { にかく悪くなったときに備えて，食料はいっぱい持っていき } \\
\text { ました（A5) }\end{array}$ & 4 & 2 \\
\hline & 13摇れ動く判断 & 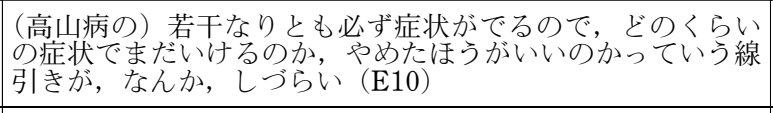 & 7 & 4 \\
\hline & 8 意識的な挑戦の設 & 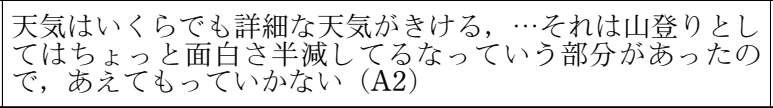 & 8 & 4 \\
\hline \multicolumn{2}{|c|}{ 困難な登山を支える意欲 } & - & - & - \\
\hline & 16登山への強い思い & \begin{tabular}{|l} 
写真見て，あ，ちょっと興奮して，興奮してすぐなんかこう \\
計画を作りたくなるわけですね \\
\end{tabular} & 8 & 6 \\
\hline & $\begin{array}{l}\text { 29挑戦で生まれる意 } \\
\text { 欲 }\end{array}$ & 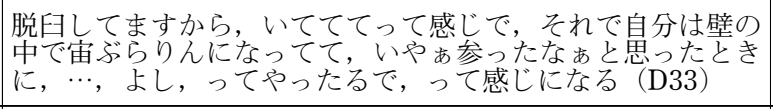 & 5 & 3 \\
\hline \multicolumn{2}{|c|}{ 14リスク軽減への最大限の努力 } & $\begin{array}{l}\text { 何一つ安全はプラスされないと思います。ただ，我々が出来 } \\
\text { るのはいかにリスクを軽減すること（D17) }\end{array}$ & 11 & 4 \\
\hline & $\begin{array}{l}3 \text { オンサイト情報に } \\
\text { よるリスク回避 }\end{array}$ & $\begin{array}{l}\text { 現地に行ってみたら，ちょっと写真でみてたのと，全然様子 } \\
\text { が違っていて，その場でルートを変えた（E60） }\end{array}$ & 20 & 6 \\
\hline & \begin{tabular}{|l}
1 最悪のシナリオ \\
想定による対処
\end{tabular} & 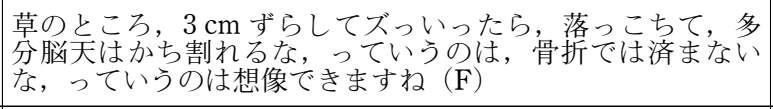 & 12 & 3 \\
\hline & $\begin{array}{l}7 \text { 詳細検討による } \\
\text { 前向き判断 }\end{array}$ & 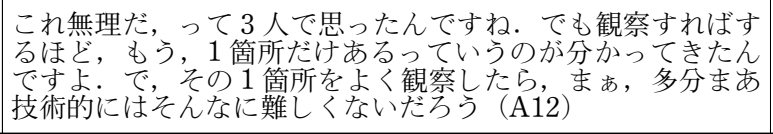 & 8 & 6 \\
\hline & $\begin{array}{l}28 \text { 制御可能部分へ } \\
\text { 集中 }\end{array}$ & 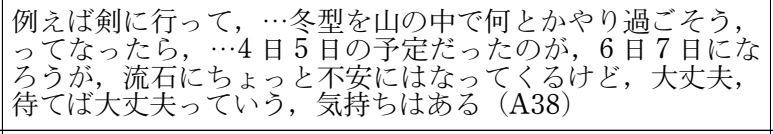 & 7 & 3 \\
\hline & 24対話による納得 & $\begin{array}{l}\text { チーム公中で, ちゃんと議論を交わして，そこから導き出さ } \\
\text { れた結論に対して，全員がちゃんとそれを受け入れるという } \\
\text { プロセスは, ‥事 }(\mathrm{A} 36)\end{array}$ & 5 & 3 \\
\hline & $\begin{array}{l}4 \text { 一般情報による事 } \\
\text { 前のリス制御 }\end{array}$ & $\begin{array}{l}\text { 早く出て早く帰ってくるとそれだけ雷に合うリスクは減った } \\
\text { りとか, タ立に合うリスクが減ったり } \\
\text { はもちろん取る }(\mathrm{C} 21)\end{array}$ & 8 & 5 \\
\hline & $\begin{array}{l}22 \text { 制御不可能性の回 } \\
\text { 避 }\end{array}$ & $\begin{array}{l}\text { 山って危険な部分はすごくあって，それを受け入れないとい } \\
\text { けない時もあるけと，僕はロシアンルーレットみたいなこと } \\
\text { はしたくなく (A11) }\end{array}$ & 13 & 6 \\
\hline
\end{tabular}


表 2 M-GTAにより産出された概念, カテゴリー，バリエーションとその産出数（つづき）

\begin{tabular}{|c|c|c|c|c|}
\hline カテゴリー名 & 概 念 名 & バリエーション & $\begin{array}{l}\text { バリエー } \\
\text { ション数 }\end{array}$ & $\begin{array}{l}\text { 産出 } \\
\text { 者数 }\end{array}$ \\
\hline \multicolumn{2}{|c|}{ 事後の相反する感情 } & - & - & - \\
\hline & 11楽観主義への反省 & 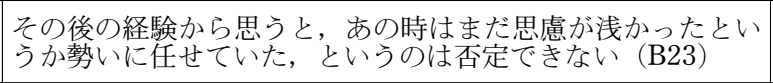 & 22 & 5 \\
\hline & 9 好運の自覚 & $\begin{array}{l}\text { ある意味ちょっと天狗になってたところもあったと思います } \\
\text { から, まあ,行けば何とかなるだろう，という軽い気持ち } \\
\text { が，やっぱあったと思います（C5) }\end{array}$ & 18 & 6 \\
\hline & $\begin{array}{l}12 \text { 経験により生ま } \\
\text { れる熟考傾向 }\end{array}$ & $\begin{array}{l}2 \text { 年続けてラッキーなことは無いだろうと思ったんですよ. } \\
\text { ここは静に考えたら，運になかるんじゃなくて，下りた } \\
\text { 方がいいんじゃないかと（B29） }\end{array}$ & 7 & 4 \\
\hline & $\begin{array}{l}23 \text { リスク判断を鈍 } \\
\text { らせる心的要因 }\end{array}$ & $\begin{array}{l}\text { その, マナスルの時だけは，もったいない，が出ましたね. } \\
\text { ほとんど後は無いですけどね.（F36） }\end{array}$ & 7 & 2 \\
\hline & $\begin{array}{l}17 \text { 熟考傾向による寂 } \\
\text { ささ }\end{array}$ & 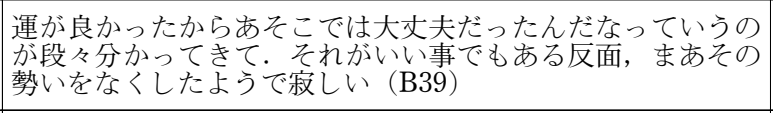 & 2 & 2 \\
\hline & $\begin{array}{l}\text { 10限界を乗り越える } \\
\text { 達成感 }\end{array}$ & $\begin{array}{l}\text { う一ん. 多分, これは，自分をコントロールするのが楽しい } \\
\text { んだと思うんですよね. 今执れてる状況で切り抜けていく } \\
\text { というか (E11) }\end{array}$ & 8 & 4 \\
\hline \multicolumn{2}{|c|}{ 登山を支える心的特性とその獲得 } & - & - & - \\
\hline & $\begin{array}{l}\text { 19学習によるリスク } \\
\text { 回避の知識 }\end{array}$ & 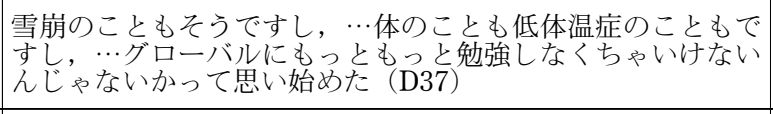 & 4 & 3 \\
\hline & 30岩壁を見る目 & 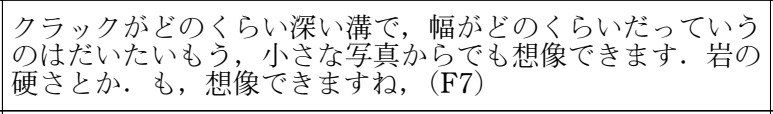 & 8 & 2 \\
\hline & $\begin{array}{l}20 \text { 経験によるリスク } \\
\text { 回避怵の習得 }\end{array}$ & 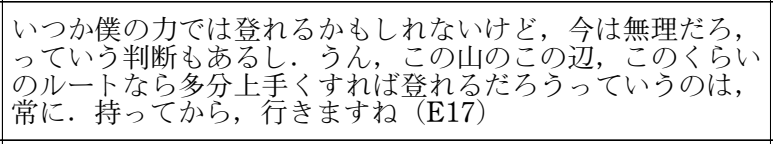 & 11 & 4 \\
\hline & 27自分の特徵への理 & 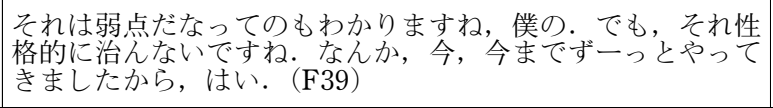 & 3 & 2 \\
\hline
\end{tabular}

†：産出者が 1 である概念は割愛した

ついては生成順に番号を振った．生成された結果 図について協力者 1 名のコメントを求めた結 果, 図に示されたようなプロセスが登山者として のスキルアップにおいて重要であることや，それ がトップの登山家とそうでないものの差を生んで いる可能性を感じ，十分妥当であるというコメン トが得られた。なお，生成者が 1 人である概念 については，一般化できない概念である可能性が あるため, 以下の検討・考察からは外した.

まず，概念とカテゴリーを概観する．［2 不確 実性の自覚 $],[31$ ミスが許されない世界 $],[25$ 困難の受容］は,【過酷な活動条件】とカテゴリー 化した。［5不確実さに対する不安］，[6 装備の
安全側への志向 $],[8$ 意識的な挑戦の設定 $],[13$ 摇れ動く判断]は，いずれも，リスクの持つ意義 と不安というジレンマ性を示すので，生成された 概念名をカテゴリーとして【18リスクの両義性 の意識】とした。また [16登山への強い思い], ［29挑戦で生まれる意欲］は【困難な登山を支え る意欲】とした。［1最悪のシナリオ想定による 対処 ], [7 詳細検討による前向き判断 $],[28$ 制御 可能部分への集中］［24対話による納得］は，い ずれも登山中の行為に伴って得られる情報に基づ くリスク対処であり, 生成された概念名をカテゴ リー名として【3 オンサイト情報によるリスク回 避】とした。これに加えて，[4一般情報による 


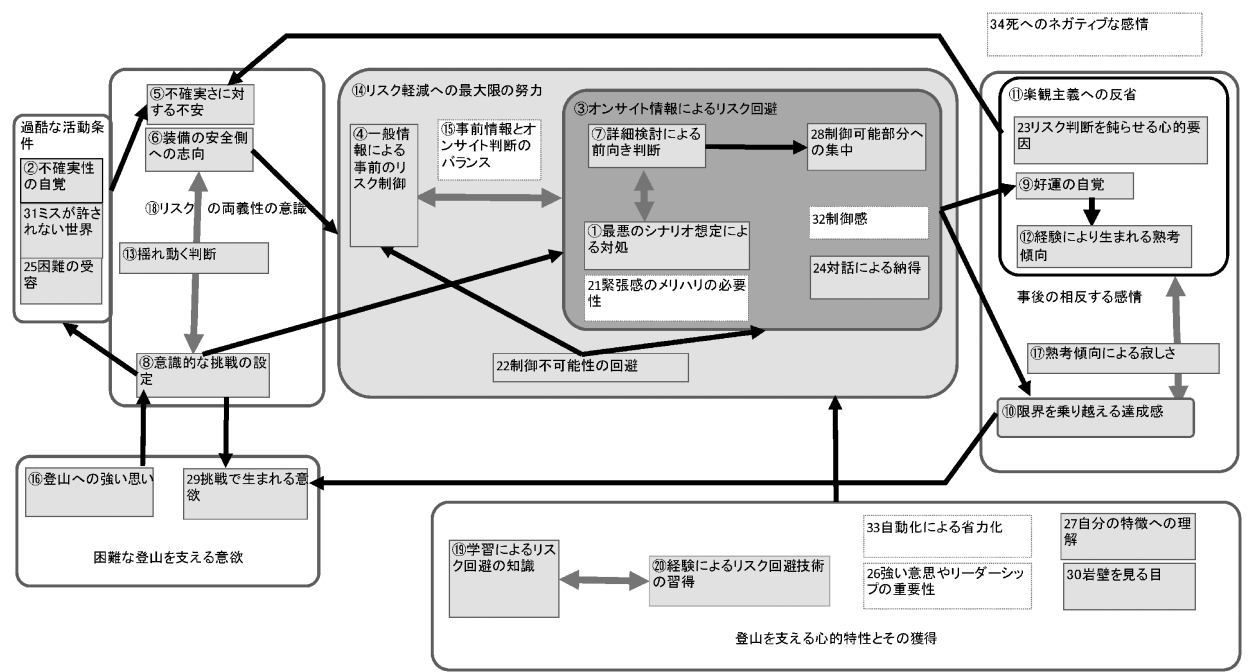

図 2 M-GTAにより得られた高所登山家のリスクの捉え，それにより喚起される感情およびリスクへ の対処方略

事前のリスク制御，［22制御不可能性の回避］ を，生成された概念名により【14リスク軽減へ の最大限の努力】カテゴリーとした．９好運の 自覚 $],[12$ 経験により生まれる熟考傾向 $],[23$ リスク判断を鈍らせる心的要因]は，リスクの高 い行為に従事したことへの反省的感情と捉え，生 成された概念名を利用して【11楽観主義への反 省】カテゴリーとした。これに [17熟考傾向に よる寂しさ，［10限界を乗り越える達成感］を 加えて,【事後の相反する感情】カテゴリーとし た。［19学習によるリスク回避の知識］，[30岩壁 を見る目 $] ，[20$ 経験によるリスク回避技術の習 得］，[27自分の特徵への理解］を，【登山を支え る心的特性とその獲得】カテゴリーとした。

分析テーマによって得られた概念・カテゴリー の相互関連を検討し，結果図とした（図 2)。高 所登山家のリスクの捉えと対処は, 登山前に生起 するリスクの両義性に基づく不安と挑戦心のジレ ンマ, 事前の一般的情報/オンサイト情報に基づ く2 局面によるリスク対処，事後の反省と達成 感という相反する感情によって特徵づけられてい た。これにより，「リスクを制御している」とい う一見矛盾したリスクへの認識を持つと同時に， 意義と危険という両義性を持つリスクに対して， 致死的な事態を回避しながら，前向きな判断によ
つて制御可能性へ集中することで，自らの能力を 最大限に発揮する挑戦を行っていた．以下，結果 図をもとにストーリーラインを詳述する。なお， $「 」 は ，$ 概念に関係したバリエーションの内容 骨子であり，（）内はバリエーション産出者の 識別記号と番号である.

高所登山家は，[16登山への強い思い］を強く 持ち,「登っている行為自体が好き（E50）」,「格 好いい（ルートを登りたい（A41)」，と考えて いた。しかし，主要未踏峰のほとんどない現代の 高所登山では，その実現のためには，「敢えて安 全手段（B16）」や「詳細な天気情報を排除する (A2)」[8 意識的な挑戦の設定 $]$ が必要であった. それにより [29挑戦で生まれる意欲］がもたら され，[16登山への強い思い］と相俟って【困難 な登山を支える意欲】が生まれた。その一方で, 「悪天候により 3 晚連続の座ったままのビバーク (B3)」,「軽度の高山病には必ずなりながらも登 る（E7）」，といった［25困難の受容］が必要で あり，[31ミスが許されない世界］という【過酷 な活動条件】の元での活動となっていた．そこに は,「自然の脅威はコントロールできない $(\mathrm{C} 18) 」$ といった，[2不確実性の自覚］が生まれた。そ れ故に, 挑戦とは相反する [5不確実さに対する 不安］が喚起され，[6 装備の安全側への志向］ 
になることもあった。挑戦と危険という【18リ スクの両義性の意識】の中で，「高山病の不安の 中でも進んだり（B26）」，「そこから先は戻れな い状況の中で進むべきか戻るか（C10）」といっ た［13摇れ動く判断］がなされていた.

登山を不確実で困難な場と捉えることが，登山 中に「1つ1つのリスクに対して確実に対応する (A34)」【14リスク軽減の最大限の努力】の原動

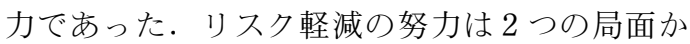
ら成り立っていた，第 1 は，「事前に入手できる 写真によるルートや装備を決定（B8, E21a）」, 「シミュレーション登山 (D8)」,「最悪の場合の ルートの設定 $(\mathrm{C} 14) 」$ 等による $[4$ 一般情報に よる事前のリスク制御】であった。第 2 は，「現 地での自分の目によるしらみつぶしのルート検討 (A28)」,「その場の気象や環境条件 (D5)」の把 握による【3 オンサイト情報によるリスク回避】 であった．前者は，一般的な知識に基づき致命的 なリスクを具体的な兆候が現れる前に回避するも のであり, 後者は, 活動中にその場で得られる （オンサイト）情報を利用してリスクに対処する ものである.

オンサイトでのリスク回避では，「霧による視

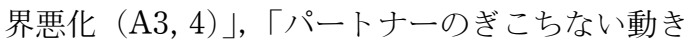
(D24)」といった，その場で得られる兆候を利用 した［1 最悪のシナリオ想定による対処］（回避） が行われていた，その一方で，具体的にシナリオ を想定することで，「ルートの弱点が見えたり (B13)」,「危機的な塗落場面でも脱出の方法を思 いつく（D40）」といった［7 詳細検討による前 向き判断］と［28制御可能部分への集中］が生 まれていた。 また，[24対話による納得］も，グ ループでの登山に抢けるリスク回避の重要な要素 であった。一般情報とオンサイト情報のいずれで も，意思決定の重要な基準は [22制御不可能性 の回避]であった．落石や落下物，あるいは「崩 壊しそうなセラック（E24）」など, 致命的なリ スクが制御不可能だと判断されれば，そこでは撤 退や予定の変更といった意思決定が行われていた.

リスク軽減を支えているのは，【登山を支える 心的特性とその獲得】である。登山中のリスク軽
減の努力を通して，実践知的に [20経験による リスク回避技術の習得］が得られるが，高リスク に対しては [19学習によるリスク回避の知識] も重視されていた。 また，[27自分の特徵への理 解］や［30岩壁を見る目］といったメタ認知的 側面も含まれていた。

登山後にも相反する感情が生まれる.「生還の 保証のない停滞 (C11)」や「周囲の仲間の死 (D14)」を経験しながらも生き残っていることに 対して,【11楽観主義への反省】が生まれていた. これは「焦り（E37）」，「他者への気遣い（F35）」 「頂上が近い（E26）」といった［23リスク判断を 鈍らせる心的要因 $]$ が働くこと, [9 好運の自覚 $]$, そこから派生する[12経験により生まれる熟考 傾向から成り立っていた。後者に対しては ［17熟考傾向による寂しさ］を感じる登山家もい た。他方で，高所登山は，[10限界を乗り越える 達成感というポジティブな感情も生起してい た. 登山後の相反する感情は, 再び登山前の葛藤 と結びついていた.【11楽観主義への反省】は次 の登山での不確実性の自覚と安全への志向を高め ていた。他方，[10限界を乗り越える達成感］は 【困難な登山を支える意欲】を喚起していた。

\section{N 考 察}

予備調査の結果も交えながら，1）高所登山家 のリスクの捉えとその心理的な意味，2）高所登 山家のリスク対処とその実践的合理性，を検討す る. また, 本研究の知見をアウトドアスポーツで のリスク対処に活用する上で重要だと思われる， 3）リスク対処を支える心的資質について考察し た後, 結果の信頼性と理論的飽和について検討す る.

\section{1. 高所登山家のリスクの捉えとその心理的な 意味}

1）不確実性の自覚

高所登山家は, 登山における不確実性を不可避 だ考えるだけでなく, むしろ積極的に求めてい た。「登山には危険という要素がある。しかし私 
は死の危険を冒すときはいつも自分がその危険を 支配できるようにしてきた。...む爫万ん最小限の 危険はないといけない。さもないと自分のやって いることが魅力のないものになってしまう（ボナ ッティ，付録 1(2))」という言葉にそれが端的に 表れている。しかしその一方で, 彼らは不確実性 に対する不安も抱いている．1980年代に最難関 ルートの登攀に立て続けに成功したポーランド人 のクルティカですら「危険な状況には不安にさせ られます…限度を超えてやった人たちはみな 死んでしまいました（付録 1(2))」, あるいは日本 を代表する登山家山野井も，準備が整って登攀を 開始する直前になると「いつものように恐怖がや

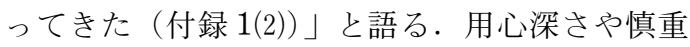
さに関する発言は多くの登山家から得られた．行 動中の多くの時間で, 登山家は知覚されたスキル より挑戦が高い不安に近い状態にいるという報告 もある (Delle Fave et al., 2003)。価值と不安の 源泉というジレンマ性を持つリスクが［13摇れ 動く判断]につながっている。

不確実性への強い自覚は事後にも見られる。多 くの高所登山家が，経験したトラブルや仲間の事 故を通して，昔より慎重になったと語った。 た，自分の直感的な行動を事後に否定的に評価 し，自分が生還できたのは運だったという【11 楽観主義への反省】が見られた．自己調整学習で は肯定的な自己評価による満足が重要だとされる が，エキスパートの逸話的な事例から，一時的に 満足度が下がっても，自己評価基準を上げて否定 的な評価を行うことが熟達化にとって重要だと示 唆されている（Zimmerman, 2006）。楽観主義へ の反省は, 次の登山時のより高いレベルでの不確 実性の自覚を可能にする手助けとなるのだろう.

2）制御できるリスク/できないリスク

高所登山家はリスクを制御できるリスクと制御 できないリスクに分け，制御できるリスク内に留 まる努力をしていた。「コントロール能力すれす れまで自分を追いつめるのは好きだが，いつもコ ントロール能力の内側にいた（ジェフ・ロウ，付 録 $1(2)) 」$. 制御できないリスクを「ロシアンルー レット（A11，22，15，26）」と呼び，忌避する登
山家もいた，インタビュー調査でも， [22制御不 可能性の回避）が全ての協力者から得られた。制 御できるかできないかは，登山においてリスクを 評価する重要な視点だと考えられる。

リスクとは本来確率的な概念であるから，制御 できるリスクとは語義矛盾である。しかし，リス クの中には，オンサイトの兆候に基づいて変化を 感知することで対処行動が可能になるものがあ る．そうではないセラックの崩壊のようなリスク を予婔除すると同時に，兆候の感知と対処が可 能なリスクについてはそれをしつづけることで, リスクを制御しているという一見矛盾した感覚を 生み出しているのだと考えられる。これが，リス クに対して分析的で精緻な見方をしない人間には 考えられないリスクの高い行動を可能にしている のであろう。

3）達成感を高めるための手段として不確実性

高所登山家は不確実性そのものを求めている訳 ではない。「明らかに大事なことは危険をしっか りと捉え，制御することです。といっても，クラ イミングには危険がなければなりません。これは はっきりいっておきましょう，危険を冒すことを 求められているのではなく，そこに危険があるこ とが求められているのです。（ロビンス，付録 1 (2)）」，「危険が次の角にひそんでいるという要素 がなかったら，登山はその独特の魅力を失う（ス

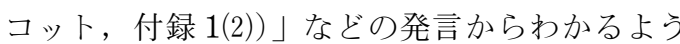
に，彼らは不確実性を求めているのではない。 登山の魅力を高めるため, 能力を少しだけ超える 挑戦を求める。そこに必然的に不確実性が付随 する。この結果は, 刺激欲求尺度による研究 (Goma-i-Freixanet, 2004） とも一致していた.

リスクが制御された中での挑戦は，リスク源と それに対する対処への集中を可能にすることで， 「判断したとおりに身体が動く気持ちよさ $(\mathrm{F}) 」$, 「視野が広いなっていう感じ（F)」といった登山 家の限界が引き上げられた体験を与えると考えら れる。これは，Csikszenthihalyi (1975) がクラ イマーへのインタビューから得た深いフロー体験 と同様のものだと考えられる. また事後には, 限 界を乗り越えた高い達成感をもたらしてくれる. 
こうした心理的報酬が，困難な登山を継続する意 欲と,リスクを制御することの喜びにつながって いると考えられる.

\section{2. 高所登山家のリスク対処とその合理性}

高所登山家は登山のリスクに対して，(1)一般的 にリスクがあるとされる要素に対する事前のリス ク制御と，(2)オンサイトのリスク情報によるその 場でのリスク回避という 2 種類の対処を行って いた．前者の代表的なものが「なだれ」「セラッ ク」「悪天候」である。これらの要素は, 高いリ スクがあるという一般的性質を持つので，その情 報は新規の山域やルートに対しても有用であり， 写真や過去の記録といった二次的情報からでも得 られる．セラックや頻繁な落石のように制御が難 しく致死的なリスクに対しては，高所登山家は回 避的に振る舞う。一方, 現場で感知できるのがオ ンサイトのリスク情報であり，その多くは変化の 兆候である. 一般的には, セラックはいつ崩壊し ても扔かくないし，崩壊すれば氷塊が降り注ぐ 致死的状況となる. しかし個々のセラックの色合 いから，変化を示す兆候が得られることもあり， そこからリスクの程度をより詳細に推測できる. リスクの程度とその推移を把握し，そこに制御可 能性が残されている場合にはリスクを保有し，才 ソサイト情報に基づくリスク回避を行う。これに より，時間や環境の変化に伴うリスクの変化に臨 機応変に対応することが可能になる.

オンサイトでは，a）オンサイト情報によるシ ナリオ想定，b)制御不可能性によるリスク回避,

c）詳細検討による前向きの判断と可能性への集 中が，リスク対処を特徵づけていた。すなわち, リスク要因や登山中に感知されたリスクの兆候に よってシナリオを予測するが，それが限界リスク を越え, なおかつ制御不可能だとされれば回避さ れる.インタビュ一対象の登山家でも，「現場に 行ってみたら，ちょっと登れるような山ではなか った（F)」といった発言が見られた。 一方で， 限界以上のリスクをスキルや努力によって回避す ることが可能だと判断されれば，前向きの判断 と，対処するための最大限の努力が行われる.
のリスク対処の方略は, 予備調査の結果と概ね一 致していた.

事前に利用可能な一般的リスク要因とオンサイ トのリスク情報を使い, 制御可能性という視点で 行うリスク判断は, 以下の 2 つ理由から高所 登山でのリスク対処方略として合理的だと考えら れる。第 1 に，この方略は高所登山に拈りり スクの両義性（村越, 2008）に対応している. 遭難死のリスクを文字通りゼロにしようとすれ ば，価值ある冒険はできない。そこで一般的なり スク要因に基づき，致死的で制御不可能なリスク を事前に回避する一方で，そうでないリスクは保 有（リスクマネジメント規格活用検討会, 2010） する。一方，登山が始まれば，リスクについての オンサイト情報が得られ，より詳細にリスクが予 測可能になるとともに，その対処の方法について も見通しが得られる。 それによって，新たに顕在 化した制御不可能で致死的なリスクを回避する. 2 つの局面でのリスク対処を行うことで, 致死的 リスクぎりぎりのところでの挑戦するに足る登山 が可能になる。第 2 に, この方略は複雑な環境 の中での行為の制御についての認知科学的知見亡 合致している。 人工知能の難問であるフレーム問 題 (McCarthy and Hayes, 1969) によれば，人 工知能が事前に与えられた知識だけで現実環境の 中で問題を解決することは不可能である. 登山で も，リスク源は事実上無限にあり，それによるト ラブルの発生確率はゼロではない。リスク低減の ため，関係ある要素を事前に検討し排除しようと すれば，いつになっても登山を始めることができ ない。しかし，現実環境では，事前知識に基づく 計画によるのとは異なるメカニズムがあり，行動 の結果として得られる情報が行動を導くのに重 要な役割を果たす。このため, フレーム問題に 陥ることなく知的行動が遂行できる。これが， アフォーダンス（Gibson, 1979）, 状況主義 (Suchman, 1987), 反省的実践家（Schoen, 1983） といった，伝統的な認知心理学の前提に異を唱え る主張の中核にある。本研究で概念化したオンサ イトでの情報とは, 対象に対して働きかけた行動 の結果として露わになるリスク情報という側面も 
ある。従って，オンサイト情報によるリスク評価 に基づいて行動を継時的に修正していくことは， これらの概念が説明しようとした行動原理と共通 性を持っていると考えられる，ただし，状況主義 やアフォーダンスの概念が，環境からの直接的な 情報による行動の制御に強く力点を置き, 計画や それを導く外界についての知識の役割を比較的軽 視するのに対して, 本研究では, 一般的な知識に 基づくリスクへの計画的対応とオンサイト情報に よるリスク対処を相補的な関係で捉えている.

\section{3. リスク対処を支える心的資質}

リスク対処に必要な資質として，対比的な概念 である [19学習によるリスク回避の知識］と [20経験によるリスク回避技術の習得］が得られ た. 前者は, 自然科学や生理学あるいは経験者の 中に蓄積された比較的顕在化された知識の獲得で ある。これらは，その性質上一般的に有効であ り,さらに経験だけでは獲得しにくいルールも含 んでいる，従って，リスクやそれによるトラブル が顕在化していない状況でも有用な可能性があ る，例えば雪崩に対する弱層テストは，雪崩の兆 候が見られない状沉でも，雪崩リスクのよい指標 になる，一方，経験によるリスク回避技術はステ ップを踏みながら実践経験の中で獲得したもので あり，それを獲得しているから「(実際に山行で 予想通りでなくても）あ，こうだったか，じゃあ こうしよう，っていうのは，こう，選択肢が自分

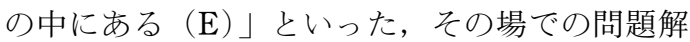
決が可能になる.

暗黙知とはもともと言語化できない知識を指す 概念（ポラニー，1980）であるが, Sternberg et al.（2000）は，通常言語的には伝達されないが， 実践的な課題解決の中で獲得され，課題遂行に資 するより広い概念として暗黙知を考えた．本研究 で明らかにした登山家の知識は, Sternberg et al.の暗黙知概念に近いものだと考えられ，言語 化しにくい直感的性質を持つと同時に，必要があ れば熟考の材料として意識的にも使われていた. 例えば，自分たちの判断の根拠について，「パパ パパパってどこが怖い，どこが危ない所だってい
うのは，もう，一瞬で分かりますね」，あるいは 「深く熟慮したうえで何とかなるっていうより も，そこは感覚的な物が大きい」といった形容が なされていた。その一方で，未知の状況や対処法 が自分のレパートリーにはない時，「(第一印象っ ていうのは，まお，これはちょっと厳しそうだな って思うんですよね，ただ））まじっくりと， その角度を変えて時間をかけ見ていくと，やっぱ りその中にも弱点が見えてきて，で，それじゃあ これは何とかいけるかも知れない（B)」といっ たように，その場で得られる情報を参照して行動 結果を予測しつつ, 問題解決行動を組み立てる対 応も見られた。こうした登山家の意思決定の特徵 は，状況に対応した過去の典型的パターンによっ て直感的意思決定をするが，うまくいかないと判 断されたら，うまくいくと予測できるまで行動を 変更する心的シミュレーションを行うことで，高 いリスクの下での適切な意思決定ができるとする Recognition Primed Decision（再認駆動意志決 定）モデル（Klein, 1998）に類似したものだと 考えられる。

一方で, 本研究では, RPD モデルでは明らか にしていないリスク下での意思決定の特徵も明ら かにされた，それは，心的シミュレーション結果 を採否する評価基準としての制御可能性や，事象 との関わりが間接的から直接的に変化する時間経 過の中で，リスク回避に利用される情報が，リス ク要因に関する一般的な知識から固有のリスクに 関するオンサイトで得られる情報へと变化する点 である、こうした点から, 本研究の結果は, 比較 的長く継続した高い能動的リスク場面での適切な 意思決定についてより広い説明力を有していると 考えられる。

第 2 の重要な心的特性として, メタ認知 (Flavell, 1979) が指摘できる.インタビュー調 査では［岩壁を見る目］［自分の特徵への理解］ が生成された，極限の状況でリスクを適切にコン トロールするためには, 自分のスキルの限界を把 握するとともに，その遂行状況を常にモニタリン グする必要がある，スキルの限界は課題との関連 によって決まるから，それは同時に課題に対する 
知識も要求する.「どういう感じの花崗岩で，ど ういうフリクションがきいて，手がどのくらい入 って，っているのでは，たぶん想像できますね (F)」といった課題の把握が，難ルートでのリス ク対処を可能にする．ただし，メタ認知に関する 概念のもととなるバリエーションは 2 人の登山 家から産出されたものの，その多くは同一の登山 家からであった。メタ認知的活動を意識して使う ことができるかどうかについては，個人差は大き いと推測される.

第 3 に，熟達化の特徴のひとつである自動化 （Chi，2006）も，意識的な活動に加えて必要だと 思われる．インタビューでは［自動化による省力 化］が，雑誌記事からは[熟練による自動化］が 得られた。「それから先の下降は，まるで入神状 態だった。・.・バランスを失って放り出される前 に，なんとかアイゼンは水をとらえた。 アイゼン は自分自身で正しいことをしている」は行動上の 自動化を示しているが，「順応に行こうとして2, 3 時間動いたところでぱっと後ろ見たとき に, ‥霧の中に, ベースキャンプが消えようと してて，これはマズイなと.もうあのべースキャ ンプなくしたらうちらおしまいだ。これはまず い」といった判断は, リスクに対する判断が，要 因をいちいち検討するようなものではなく，状況 によって自動的に駆動されるもの（Klein，1998） である可能性を伺わせる．こうした行動と判断の 自動化が, 過酷な状況下での確実なリスク対処に つながり, 生存の可能性を高めていると思われる.

最後に，一見矛盾する複数の行動原理の共存を 許す点である。登山家は登山に対する強い魅力を 感じ，困難にあえて取り組んでいるが，一方で臆 病だと自分自身を形容し，それに由来する不安を 指摘していた。これらは行為にネガティブな影響 を及ぼす反面，不安は「リスクへの抜け目のない アドバイザー」(Long, 1989) となりえる.また， 雑誌記事からは，[能力を超えた現実に対する諦 めのよさ）と同時に［諦めずに全力を尽くす］と いった，矛盾する意識が見出された．複雑な環境 下で限界レベルを追求する時, 単一の原理では極 端な意思決定に陥りやすいのかもしれない, 挑戦
と臆病さ，あるいは諦めのよさと諦めない意思の 強さという相反する複数の行動原理を持つこと が，致死的リスク下ぎりぎりでのリスク対処を可 能にし, 生存を保障しているのだと考えられる.

\section{4. 理論的飽和と結果の信頼性}

調査対象となった 6 名の高所登山家から生成 された概念数は異なっており, 最も多い A で23 個，最も少ないCで12の概念が生成された．協 力者間で生成された概念は異なるものの，不確実 性に対する不安, 挑戦と不安のジレンマ, オンサ イトでのリスク回避と制御不可能性による回避, 好運の自覚といった中核となる概念は全ての協力 者から生成され，相反する感情も 4 名の協力者 から得られた. さらに，6人の協力者中 5 番目に インタビュー面接を行った $\mathrm{E}$ から得られた新し い概念は $1 つ ， 6$ 番目の $\mathrm{F}$ からは 3 つの新しい 概念が得られたが，それらはいずれもリスク把握 と対処のプロセスではなく, 心的特性カテゴリー に属するものであった，また，概念ごとに得られ たバリエーションの数も, [不確実性の自覚］[才 ンサイト情報によりリスク回避］[最悪のシナリ 才想定による対処］[制御不可能性の回避］[楽観 主義への反省］[好運の自覚）といった中核的な 概念では協力者 1 人あたりの平均産出数がすべ て2を超えていた，以上のことから，意欲の持 ち方や心的資質は異なるものの, 核となる不確実 性の自覚やそれによるジレンマ, リスク軽減の努 カやリスク対処に打ける一般情報とオンサイト情 報の利用, 制御不可能性を回避する方略には高い 共通性が見られた。

対象者の 6 名という数は一般的な基準から言 えば少ないが, 特殊な活動では, 比較的少数で理 論的飽和に達するという報告がある（Schneider et al., 2007). 本研究の協力者のうち 5 名が国際 的な賞を受賞した高所登山家であり, 他の 1 名も 国内ではそれに匹敵する登攀経験のある登山家で ある，彼らが従事する高所登山のように，特殊か つ極限的でのリスク対処という合目的的活動にお いては, 理論的飽和には同様の特徵があると期待 できる。また得られた概念や過程は，より広範囲 
に収集された登山のリスクに関する雑誌・書籍の 記事から得られた予備調查の結果とも一致してい た. 以上のことから，リスクの捉え方と対処の中 核的な過程については，本研究の結果は概ね飽和 しており, 高所登山家のリスクの捉えとリスク対 処の全体像を適切に捉えていると判断できる.

3 人の著者の概念抽出の比較から，抽出された 概念には一定の違いが見られた，登山を実践して いない第 2 -第 3 著者では，より抽象的な名称を 持った概念が生成される傾向にあった。木下 (2007) も指摘しているように, M-GTA に抢ける 概念の命名は, 研究者の経験やそれに基づく視点 に強く影響を受けているものと考えられる。その 一方で，抽出した概念を元にした結果図の中核に おいては，3者において一致が見られた。こうし た点から，概念名は異なるものの，生成された中 核的な概念そのものや，その関係を示す結果図に ついては一定の信頼性が確保されていると同時に, 対象領域に関して経験と知識の少ない者にとって も了解可能で，妥当なものであると考えられる.

\section{V リスク対処への一般的示唆, 展望お よび課題}

学校教育はもちろん，一般的な自然体験活動で も死と隣り合わせの活動をすることは考えにく い。しかし，超えてはならないリスクのレベルが あると考えている点では，高所登山家も一般の体 験活動の指導者も共通している，だとすれば，高 所登山家のリスクの捉え方や対処は，リスクのレ ベルでは一般アウトドアスポーツとは大きな隔た りがあったとしても，超えてはならないレベルを 維持してリスクに対処するという点に関して，一 般的な登山や自然体験活動に対して示唆をなしえ るであろう。

まず，自然が不確実な場であることとそれが産 み出すリスクの両義性についての自覚である。例 えば，近年多くの軽微な山岳遭難が発生している が，登山者の不安や危険の認識は必ずしも高くな い（例えば，山本，2010）。一方，リスクの両義 性については，2001年に発生した岐阜県板取村
での落石による中学生死亡事故は, 雨がやんだ状 況下で，生徒にできるだけ意義ある活動をさせた いという教員の思いからハイキングが決行された ことにも要因があったことが推測されている（村 越，2008). 不確実性があるからこそ活動として 教育的意義がある反面，それが予期せぬ出来事と してのリスクを生み出す。リスクとその両義性を 意識した安全管理のあり方が模索されている（例 えば，布目，2011）が，リスクを保有しつつ対 処する実践的な方法論については十分確立されて いない。登山のリスクに関する書籍(例えば，昆， 2013 ; 丸山・羽根田，2001), あるいは山岳雑誌 で定期的に特集されるリスクマネジメントのいず れにおいても，方略的視点は希薄である. 本研究 によって得られた 2 種類の情報に基づきリスク を把握し，事前とオンサイトという 2 つ局面 でリスクに対処すること，制御可能性を重要な判 断基準とすることは, リスクから意義を引き出し ながら，リスクに対処する汎用性の高い指針を与 えてくれると考えられる.

とりわけ，不確実性のある自然の中での活動に おける計画と臨機応変さについて, 本研究は以下 のような再解釈を与えてくれる。すなわち，高所 登山家のリスク対処がオンサイトに多くを依存し ているということは，計画が不要であることを意 味しない，オンサイト情報に基づくリスク対処 は，文字通り臨機応変なリスク対処である。しか し，その機に臨んでは手遅れなリスクもある。例 えば，都会ならのどが乾けばいつでも飲久物を確 保できる．一方自然の中では，のどの乾きという 兆候を得てからでは手遅れになる可能性もあり, 一般的なリスク情報による計画的行動が不可欠で ある. 計画によって致死的事態の回避が保障され ているからこそ, 状況的行為 (Suchman, 1987) が有効となる。 また，臨機応変さに関して，それ が有効な対処方略であるのは，(1)事前には十分な 情報が得られず具体的な意思決定ができないが， (2)オンサイト情報によってリスクの变化を予測で き，さらに(3)行動の帰結が制御可能である，場合 である、(1)は臨機応変さの必要条件であり, (2)(3) は臨機応変さが適切な意思決定となる十分条件で 
ある。(2)(3の十分条件を意識することが，臨機応 変さをリスクマネジメントの中に適切に組み込む ことにつながるという示唆も得られた。

活動後の楽観主義への反省についても, 本研究 の結果は示唆的である. 多くの活動は成功裏に終 わる. 成功が達成感や喜びの源泉であり, 活動の 意義であることは論を俟たない。その一方で，リ スクがあるとは，そこに事故の可能性が残ること を意味する，その可能性に対する意識を高めてく れるものとして事故には至らないが危なかった事 例であるヒヤリ（ハット）報告（谷村，1995） がある。産業界や医療・福祉の分野では取り組 み事例があるものの, 自然体験活動では村越 （2006）や村越·若月（2007）などを除いて活用 報告はほとんど見られない。活動後の省察によっ て，ヒヤリハットから派生する可能性のある帰結 に目を向けることが，次の活動に抢ける不確実性 の自覚や具体的なリスク対処への意識につながる と考えられる.

最後に質的研究である本研究の限界や課題につ いて指摘する。まず，本研究で得られた高所登山 家のリスク対処は, 彼らの主観的な意味付けによ るものであるという点である。それは，登山とい う不確実性の多い行為への態度や行動についての 納得感の高い説明や指針を与えてくれるものの, リスクマネジメントの実効性については担保され ているわけではない。 また，1つ1つの概念はバ リエーションに対応しているという意味で高所登 山家の中で心理的なリアリティとして存在すると 考えられるが，それを再文脈化することで得られ た関係性やプロセスについては，研究者の解釈の 結果であり，それが登山家にとって心理的なリア リティーのあるものかどうかについては，協力者 の 1 人が共感を示したものの十分に保証されて いる訳ではない。これらの研究上の課題に対応す るためには，実際の高所登山やそれに準じる現場 での判断やそこでの発話プロトコルなどの，より 客観的で直接的な行動の分析が必要であろう。ま た，得られた概念を質問紙化し，高所登山家と一 般の登山者や, 高所登山の経験による比較を行う といった検討も必要であろう。本研究の知見は,
こうしたより客観性の高い研究への重要な一歩に なると考えられる。

\section{謝辞}

本研究は科学研究費補助金（平成23-24年度 課題番号 23650387 , 研究代表者：村越真）によ り行われたものである. 調査場所の提供をいただ いた国立登山研修所拈よび調査協力者の高所登山 家の皆様に感謝します.

\section{注}

注 1) 高所登山

本研究では, 高所での低酸素, 低温などの厳しい条 件下で行われ，多くの場合ロープによる確保を必要と する高リスクの登山を意味する。それに従事する者を 高所登山家とする，ただし，文脈上䛊解のない場合に は，登山ないし登山家と記述した。

注 2) リスク

狭義のリスクとは行動の結果として確率的に発生す る損害を意味し，一般的には損害 $\times$ 確率で定義され る. 登山活動のリスクは活動内容や個人のスキルによ って損害や確率が異なるため定量化は困難であり, 本 来は「不確実性」(木下，2000）と呼ぶべきものである.

しかし, 多くの先行研究でも登山等の活動における危 険性はリスクと記されている。一方，不確実性は一般 的には結果の良し悪しを問題にしない概念として使わ れる、そこで本研究では, 損害を強く含意した不確実 な事象を「リスク」, 損害を含意せず単に結果が分から ない事象を「不確実性」と呼ぶ.

\section{文献}

Chi, M.T.H. (2006) Two approaches to the study of experts' characteristics. In: Ericsson, K.A., Charness, N., Feltovich, P., and Hoffman, R.R. (Eds.) The Cambridge handbook of expertise and expert performance. Cambridge University Press: New York, pp. 21-30.

Csikszenthihalyi, M. (1975) Beyond boredom and anxiety. Josseyb-ass: San Francisco.

Delle Fave, A., Bassi, M., and Massimini, F. (2003) Quality of experience and risk perception in high-altitude rock climbing. Journal of Applied Sport Psychology, $15(1)$ : 82-98.

Ewert, A.W. (1994) Playing the edge: Motivation and risk taking in a high-altitude wilderness like environ- 
ment. Environment and Behavior, 26: 3-24.

Eysenck, S.B.G. and Eysenck, H.J. (1977). The place of implusiveness in a dimensional system of personality description. British Journal of Social and Clinical Psychology, 16: 57-68.

Flavell, J.H. (1979) Metacognition and cognitive monitoring: A new area of cognitive-developmental inquiry. American Psychologist, 34: 906-911.

Gibson, J.J. (1979). The ecological approach to visual perception. Houghton Mifflin Co.: Boston.

Goma-i-Freixanet, M. (1991) Personality profile of subjects engaged in high physical risk sports. Personality and Individual Differences, 12: 1087-1093.

Goma-i-Freixanet, M. (2004) Sensation seeking and participation in physical risk sports. In: Stelmack, R.M. (Ed.) On the psychobiology of personality: essays in honor of Marvin Zuckerman. Elsevier: New York, pp. 185-201.

Heimer, C.A. (1988) Social structure, psychology, and the estimation of risk. Annual Review of Sociology, 14: 491-519.

Jack, S.J. and Ronan, K.R. (1998) Sensation seeking among high- and low-risk sports participants. Personality and Individual Differences, 25: 1063-1083.

Jakus, P.M. and Shaw, W.D. (1996) An empirical analysis of rock climbers' response to hazard warnings. Risk Analysis, 16: 581-586.

金井壽宏・楠見 孝 (2012) 実践知. 有斐閣 : 東京.

川喜多二郎 (1967) 発想法. 中央公論社 : 東京.

警察庁生活安全局地域課（2013）平成24年中における 山岳遭難の概況.

http://www.npa.go.jp/safetylife/chiiki28/h24_sanga kusounan.pdf，(参照日2013年10月18日）

木下冨雄（2000）1. 不確実性・不安そしてリスク。日 本リスク研究学会編, リスク学事典. TBSブリタニ 力: 東京, pp. 13-15.

木下 康仁 (2003) グラウンデッド・セオリー・アプ ローチの実践一質的研究への誘い. 弘文堂 : 東京.

木下 康仁 (2007) ライブ講義 M-GTA：実践的質的 研究法 修正版グラウンデッド・セオリー・アプ ローチの全て. 弘文堂 : 東京.

Klein, G. (1998) Sources of power: How people make decisions. The MIT Press: Massachusetts.

昆和正 (2013) 山で正しく道に迷う本. 日刊工業新 聞社 : 東京.

Langer, E.J. (1975) The illusion of control. Journal of personality and Social psychology, 32: 311-328.
Llewellyn, D.J. and Sanchez, X. (2008) Individual differences and risk taking in rock climbing. Psychology of Sport and Exercise, 9: 413-426.

Llewellyn, D.J., Sanchez, X., Asghar, A., and Jones, G. (2008) Self-efficacy, risk taking and performance in rock climbing. Personality and Individual Differences, 45: $75-81$.

Long, J. (1989) How to rock climb! Chockstone Press: Colorado.

McCarthy, J. and Hayes, P.J. (1969) Some philosophical problems from the standpoint of artificial intelligence. Machine Intelligence, 4, 463-502.

Martha, C., Sanchez, X., and Goma-i-Freixanet, M. (2009) Risk perception as a function of risk exposure amongst rock climbers. Psychology of Sport and Exercise, 10: 193-200.

丸山晴弘 · 羽根田治 (2001) 山の危険. 山と渓谷社 : 東京.

村越 真（2006）自然体験活動におけるヒヤリ・ハッ 卜事例の分析. 静岡大学教育学部研究報告 (教科教 育学篇), 37: 203-210.

村越 真（2008）野外活動指導者は危険をどうとらえ ているか. 静岡大学教育学部研究報告 (教科教育学 篇), 39: 237-248.

村越 真·若月朋子（2007）組織キャンプにおける指 導者抢よびキャンパーのヒヤリ・ハット事例の認 知. 野外教育研究, 11: 49-58.

布目靖則（2011）この本を読むまえに. 自然体験活動 研究会編, 野外教育における安全管理と安全学習. 杏林書院：東京, iii-iv.

ポラニー：佐藤敬三訳 (1980) 暗黙知の次元 : 言語か ら非言語へ。紀伊國屋書店：東京. 〈Polanyi, M. (1966) The tacit dimension. University of Chicago press: Chicago.>

リスクマネジメント規格活用検討会編著 (2010) ISO31000: 2009 リスクネジメント解説と適用ガイ ド. 日本規格協会 : 東京.

Ross, K.G., Shafer, J.L., and Klein, G. (2006) Professional judgements and "Naturalistic Decision making." In: Ericsson, K.A., Charness, N., Feltovich, P., and Hoffman, R.R. (Eds.) The Cambridge handbook of expertise and expert performance. Cambridge University Press: New York, pp. 403-419.

Schneider, T.A, Butryn, T.M., Furst, D.M., and Masucci, M.A. (2007) A qualitative examination of risk among elite adventure racers. Journal of Sport Behavior, 30: 330-357. 
Schoen, D.A. (1983) The reflective practitioner: How professionals think in action. Basic Books: New York. 塩野米松（2011）心を「研ぎ澄ます」8000 m 峰に挑む 登山家の独白 竹内洋岳「死と向き合うからこそ, 死を避けられる」. スポーツグラフィックナンバー, No. 781: 58-62.

Sternberg, R.J., Forsythe, G.B., Hudlund, J., Horvath, J.A., Wagner, R.K., Williams, W.E., Snook, S.A., and Grigorenko, E.L. (2000) Practical intelligence in everyday life. Cambridge University Press: Cambridge, UK.

Suchman, L.A. (1987) Plans and situated actions: The problem of human-machine communication. Cambridge University Press: Cambridge, UK.

谷村冨夫 (1995) ヒューマンエラーの分析と防止. 日 科技連：東京.

Weinstein, N.D. (1980) Unrealistic optimism about future life events. Journal of Personality and Social Psychology, 39: 806-820.

Woodman, T., Barlow, M., Bandura, C., Hill, M., Kupciw, D., and Macgregor, A. (2013). Not all risks are equal: The risk taking inventory for high-risk sports. Journal of Sport and Exercise Psychology, 35: 479-92.

山本清龍（2010）富士山に抢ける登山者属性と認識さ れた不安抢よび危険に関する研究. ランドスケープ 研究, 73: 485-48.

Zimmerman, B.J. (2006) Development and adaptation of expertise: The role of self-regulatory processes and beliefs. In: Ericsson, K.A., Charness, N., Feltovich, P., and Hoffman, R.R. (Eds.) The Cambridge handbook of expertise and expert performance. Cambridge University Press: New York, pp. 705-722.

Zuckerman, M. (2007) Sensation seeking and risky behavior. American Psychological Association: Washington, DC.

Zuckerman, M. and Kuhlman, D.M. (2000) Personality and risk-taking: Common biosocial factors. Journal of Personality, 68: 999-1029.

付録 1 : 資料とした雑誌記事・インタビュ一記録

口書籍

(1)メスナー, R. (2011) ナンガ・パルバート単独行. 山と渓谷社 : 東京.

(2)オコネル，N．（1996）ビヨンド・リスク：世界のク
ライマー 17 人が語る冒険の思想. 山と渓谷社 : 東京. (3)山野井泰史 (2004) 垂直の記憶. 山と渓谷社 : 東京.

雑誌記事

(4)ババノフ, V. (2009) カラコルム連続登攀「その 1, $2 」$. 岳人, 2009 年 2 月号 : 138-153.

(5)ファウラー, M. (2009) 西壁の罰ゲーム. 岳人, 2009年 5 月号 : 146-153.

(6)平塚晶人 (2009) 谷口けい (インタビュー). 山と渓 谷，2009年12月号 : 126-129.

(7)藏本悠介 (2010) ヒマラヤの未踏峰を夢見て. 岳人, 2010年 4 月号 : 51-55.

(8)馬目弘仁 (2007) 憧憬の頂 : インドヒマラヤ・メル 一中央峰北東壁 シャークフィン $(6450 \mathrm{~m})$. 岳人, 2007年 2 月号.

(9)竹内洋岳 (2006) ヒマラヤ新時代への挑戦. 山と渓 谷, 2006年 9 月号：186-189, 10月号：188-191, 11 月号：192-195, 2007年 1 月号：180-183, 2 月号： 220-223, 3 月号154-157.

(10)田辺 治（2007） ローツェ南壁冬季初登攀. 山と渓 谷，2007年 3 月号 : 248-251.

(11)長門敬明（2010）天野和明・増本亮・長門敬明 デ ナリ・ダイヤモンド オールフリー初登攀. 岳人, 2010年 8 月号 : 146-153.

(12)ピュリャー, J. (2009) ネパールのワイルド・サイ ド. 岳人, 2009 年 7 月号 : 147-153.

(13)ピュリヤー, J. (2010) 未踏峰と氷壁登攀 ロルワー リンの二ヶ月. 岳人, 2010 年 6 月号 : 143-149.

(14)山野井泰史（2006）極限のソロ：バフィン島「トー ル西壁」単独登攀. 山と渓谷, 2006年 3 月号 : 4041.

(15)山野井泰史（2006）書かれなかった「垂直の記憶」.

山と渓谷, 2006年 3 月号 : 68-71.

(16)山野井泰史（2010）山野井泰史のこの道（2-4）（聞 き書き佐藤次郎）岳人，2010年 10 月号 : 79-84, 11 月号 : 62-67, 12月号 : 62-67.

(17)横山勝丘 (2007) 錫杖岳からカンテガ北壁へ. 岳人, 2007年 5 月号 : 18-24.

(18)横山勝丘（2010）忍耐と幸運の壁：ラトック I 峰北 面. 岳人, 2010 年10月号 : 150-158.

$\left(\begin{array}{l}\text { 平成 } 26 \text { 年 } 3 \text { 月 } 25 \text { 日受付 } \\ \text { 平成 } 26 \text { 年 } 8 \text { 月 } 18 \text { 日受理 }\end{array}\right)$

Advance Publication by J-STAGE Published online 2014/10/27 